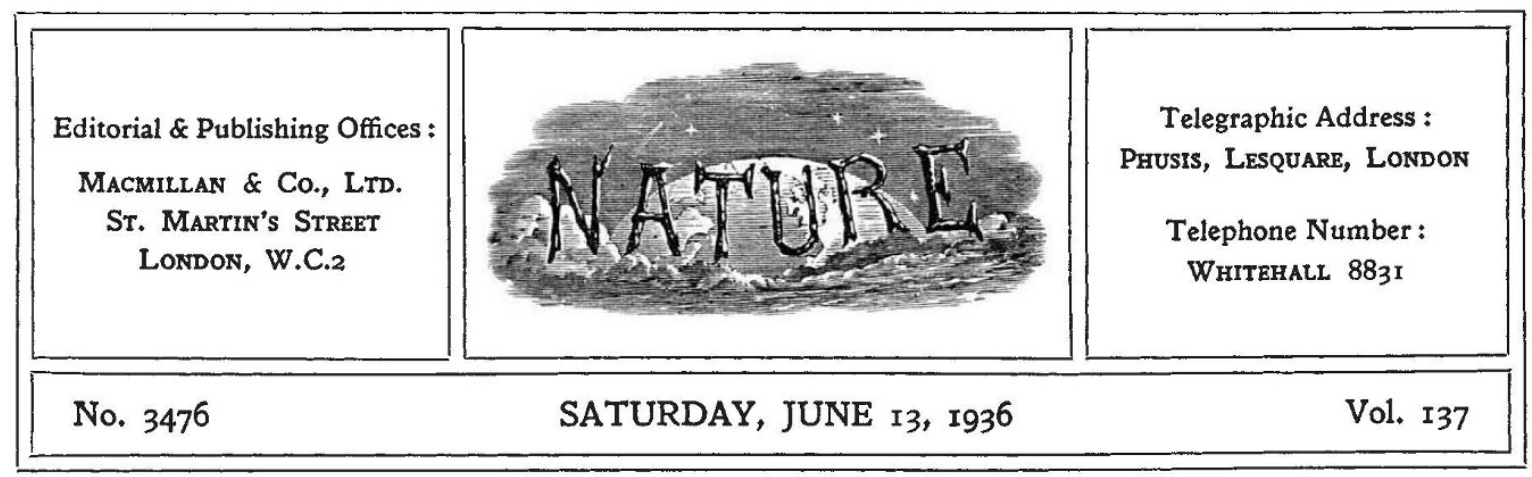

\title{
The Protection of Scientific Freedom
}

W HEN the Academic Assistance Council was formed in May of last year to assist scientific and other scholars who, on grounds of religion, race or opinion, were unable to continue their work in their own country, it was hoped that its work might be required for a temporary period only. In co-operation with other emergency organisations, the Council has succeeded in permanently re-establishing 363 of the 700 displaced scholars who left Germany, and in providing temporary support for 324 others in universities and other institutions of learning while continuing their research. A feature of this work has been the ready co-operation which the Council has secured from practically all university institutions in giving an opportunity to those displaced of continuing their scientific and learned pursuits.

It is now clear that some permanent body is needed to assist scholars who are victims of political and religious persecutions. The devastation of the German universities still continues, and in Russia and Italy freedom of study and teaching in large portions of the field of learning are still proscribed. Within the past year in Portugal, a number of university teachers in various faculties have been retired on grounds of political opinion, and the Council has offered its assistance to them. In these eircumstances the Academic Assistance Council has decided to establish as its permanent successor a 'Society for the Protection of Science and Learning', which will continue its various forms of assistance to scholars of any country who on grounds of religion, race or opinion are unable to carry on the scientific work for which they are qualified. The Society will be incorporated as a company limited by guarantee, and one of its functions will be to build up an Academic Assistance Fund to award research fellowships tenable in the Universities of Great Britain and other countries by the most distinguished of the refugee scholars.

The issue of this appeal is a pertinent reminder of the dangers to civic freedom and responsibility existing in some countries at the present time. Political events of the last four years have, moreover, struck heavy blows at the international solidarity of science itself. It is not merely the displacement of many workers of outstanding ability from Germany and other countries and the consequent enrichment of intellectual life elsewhere. The resulting impoverishment of scientific life is less disquieting than the effect of lopsided development of science in one such country on developments elsewhere. The prostitution of scientific effort on war purposes to the extent and intensity which we have been witnessing in Germany and Italy, for example, constitutes exactly that threat to peace which Major Lefebure pointed out in the "Riddle of the Rhine" in 1919 was to be found in the uneven development of chemical industry.

The position of the scientific worker under a dictatorship is in fact one of the greatest difficulties in the way of the formulation and acceptance of a code of professional ethics in such matters as the application of scientific effort in warfare. Even in Great Britain and in France, however, professional organisations have largely still to acquire the sense of civic or social responsibility which can inspire either the formulation of such codes or ensure their observance in practice. Scientific workers are rapidly becoming aware of the extent to which political organisations can affect the direction of scientific research, and even frustrate its efforts, but they have shown little sign collectively that they are aware of what is 
demanded of them even in the interests of science itself.

The reason for this position lies in the failure to understand the nature of organised society and to recognise simple social truths which is a consequence of our neglect of training for citizenship. The scientific worker suffers on the whole more rather than less than other members of the community from this neglect. The very extent to which scientific factors enter into the problems of government and administration on any scale to-day make it as imperative that some training in citizenship should form a part of his training, as that the ordinary citizen should receive in his education at least a sufficient training in science to provide a background for the life he is called upon to live.

The task before us indeed is that of organising society from the civic or municipal through the national to the international plane, in accordance with a social policy which permits the fullest flow of creative thought and activity and the maximum enjoyment of the resources at our command. That task demands the fullest participation of the scientific worker, alike in ascertaining the facts upon which action must be based and in contributing to the vital creative thought which shapes new means and new policies adequate under the conditions of to-day. Unless he is prepared to co-operate, we may well see the gradual dying down of creative thought and activity no less in science than in the political and other fields.

The limiting influence of politics upon scientific work is in fact making itself felt at a time when the service men of science might render is of increasing magnitude and importance. Not merely are new fields of investigation opening up before him, such as the whole subject of population in its biological, statistical and social aspects, but also the spirit of disinterested inquiry, of unprejudiced search for truth and willingness to face and accept change which characterises the mind of science, are needed as never before. Until some of our major problems can be sifted out in this spirit, we are unlikely to regain our control over events.

Nowhere is this more true than of administration itself. The emergence of scientific management indicates that we are slowly coming to realise that organisation is a subject for scientific study and that there are definite principles which must be discovered and respected if we are to avoid the disintegration either of society or of industry under the influence of mechanisation and other forces.
The science of management is as yet in its infancy, and probably no factor is more responsible for dissatisfaction, inefficiency and injustice either in industry or in society than the neglect of sound principles of management which have been discovered partly by experience and partly by deliberate investigation.

The knowledge that such principles exist and can be applied to overcome many of our difficulties is itself an inspiration to the scientific as to the social worker. Equally important with his con. tribution to the evolution of appropriate organisation is the stimulus which his willingness to accept and promote change can supply. It supplies a corrective to the inherent tendency to pay greater respect to the administration than to the creative function, and to the resistance to reintegration and adaptation of institutions which have outlived their utility or ceased to function. The kinship between the spirit of service and the spirit of science enhances the value of this contribution.

Moreover, with this willingness to face change, there is usually linked in the mind of science a capacity for continuous evolution by building on the past and modifying its institutions to meet the changed conditions, which offers a means of building a new social order without recourse to the violent and revolutionary measures adopted in some countries. Within our existing framework the continuous and impartial application of existing knowledge might do much to establish such an order and evolve new and more creative standards of life and thought.

The participation of the scientific worker in this task is not merely a matter for the individual. Education in citizenship may indeed make him more aware of his responsibilities and opportunities and lead him to participate more fully in civil and social life. It is, however, professionally that his major contribution will still be rendered, and professional organisations occupy a place in society of decisive importance. Without this assistance we may look in vain for the emergence of leadership of an adequate calibre or for that close relation between knowledge and power which alone can avert catastrophe. It is mainly from within their own rank that men of science will find the support that enables them still to maintain the vital freedom of thought and investigation without which assuredly our present civilisation is doomed. The Society for the Protection of Science and Learning should at least ensure that that support is maintained, and indeed augmented. 